\title{
Academic Taekwondo realized: A report on the International Academic Conference for Taekwondo (iACT) 2019
}

\author{
John A. JOHNSON* \\ Department of Taekwondo, College of Physical Education, Keimyung University (Republic of Korea)
}

Recepción: 12/03/2019; Aceptación: 24/05/2019; Publicación: 25/05/2019.

\begin{abstract}
The International Academic Conference for Taekwondo (iACT) 2019 was held from February 17-18 at Stanford University. The two-day conference featured numerous taekwondo social science researchers and scholars from around the world and several international taekwondo organizations. iACT 2019 was the first time an academic conference on taekwondo-or any combat sport-was held at a world-renown, elite-level university. Holding iACT 2019 at Stanford University validated taekwondo's researchers and their ideas and unquestionably legitimized taekwondo as an academic research field. This report outlines the conference's events and summarizes the most poignant concepts presented at iACT 2019.
\end{abstract}

Keywords: Taekwondo; International Taekwon-Do Federation; ITF; World Taekwondo; WT; martial arts; combat sports; academic conference.

El Taekwondo Académico hecho realidad: informe sobre la International Academic Conference for Taekwondo (iACT) 2019

\section{Resumen}

La International Academic Conference for Taekwondo (iACT) 2019 se celebró los días 17 y 18 de febrero en la Universidad de Stanford. Contó con numerosos investigadores del ámbito de las ciencias sociales, académicos de taekwondo de todo el mundo y diversas organizaciones internacionales ligadas al taekwondo. Esta ha sido la primera vez que una conferencia académica sobre este o cualquier deporte de combate se ha llevado a cabo en una universidad de élite de renombre mundial. La celebración de la iACT 2019 en la Universidad de Stanford confirmó a los investigadores de taekwondo y sus ideas y sin duda, legitimó al taekwondo como un campo de investigación académico. Este informe resume los eventos de la conferencia y resume los conceptos más destacables presentados en la iACT 2019.

Palabras clave: Taekwondo; Federación Internacional de Taekwon-Do; ITF; World Taekwondo; WT; artes marciales; deportes de combate.
O Taekwondo Académico se torna realidade:

Relatório sobre a International Academic

Conference for Taekwondo (iACT) 2019

\section{Resumo}

A International Academic Conference for Taekwondo (iACT) 2019 foi realizada de 17 a 18 de fevereiro na Universidade de Stanford. A conferência contou com muitos investigadores de ciências sociais, académicos internacionais que têm por objeto de estudo o taekwondo e várias organizações internacionais deste desporto de combate. Com a iACT 2019, foi a primeira vez que se realizou uma conferência académica sobre o taekwondo numa universidade de elite de renome mundial. A realização do iACT 2019, na Universidade de Stanford, permitiu a troca de informação entre os investigadores de taekwondo, legitimando, inquestionavelmente, este desporto como um campo de pesquisa académica. Este relatório descreve os eventos da conferência e resume os conceitos mais pungentes apresentados no iACT 2019.

Palavras-chave: Taekwondo, Federação Internacional de Taekwondo; ITF; World Taekwondo; WT; artes marciais; desportos de combate.

\section{Introduction}

The International Academic Conference for Taekwondo (iACT) 2019 was held February 1718, 2019 at Stanford University's Arrillaga Family Sports Center (Figure 1). The conference, which was the third such event organized by Drs. Ron Dziwenka (Salisbury University; Salisbury, MD; United States) and John A. Johnson (Keimyung University; Daegu, Republic of Korea [ROK]) to highlight the multidisciplinary researches in the martial art and combat sport aspects of taekwondo, was the first time an academic conference on taekwondo-or any combat sport-was held at a world-renown, elite-level university.

${ }^{*}$ E-mail: beowulf600@gmail.com 


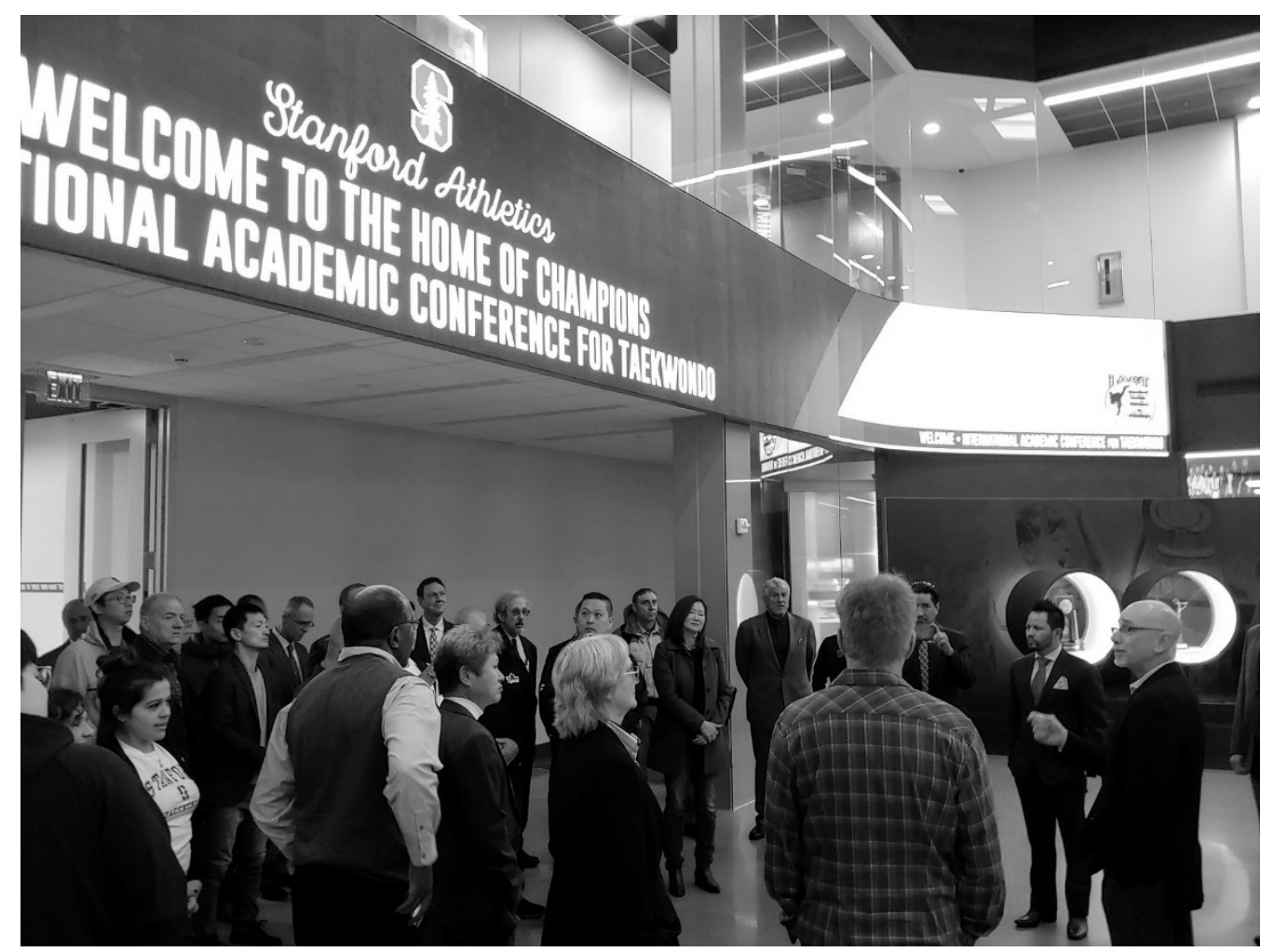

Figure 1. iACT 2019. Speakers and attendees tour the Home of Champions exhibit hall at Stanford University's Arrillaga Family Sports Center.

The conference's organizing committee consisted of: Dr. Ron Dziwenka, Dr. John A. Johnson, Dr. Dafna Zur (Stanford University; Center for East Asian Studies; United States), Coach Tim Ghormley (Stanford University; Stanford Athletics; United States), and (taekwondo Master) Justin Castillo (Las Cruces, New Mexico; United States). Operating on a grassroots budget, iACT 2019 was sponsored by Grand Master Woo Jin Jung (Tae Kwon Do Times magazine), Grand Master Herb Perez (Gold Medal Martial Arts), Ali Ghafour (20/20 Armor), Master Jim Rennie, Jr. (Whitecourt Taekwondo), James Kim (Mooto USA), Master Justin Castillo (Maximum Martial Arts), and Jin Song (Daedo Truescore International). It was further supported by many distinguished academicians, such as Dr. Jun Uchida (Director; Center for East Asian Studies; Stanford University), Professor Ken Min (Director; International Martial Arts Research Institution; University of California, Berkeley), and Dr. Russell Ahn (Director; Martial Arts Program; University of California Berkeley).

Most importantly, iACT 2019 featured presenters representing numerous national, regional, and international academic and martial arts organizations, including World Taekwondo (WT; the governing body for international competitions of the Olympic style of taekwondo), International Taekwon-Do Federation (ITF), and the Kukkiwon (the education center for Olympic taekwondo). World Taekwondo Europe was represented by Professor Franjo Prot (University of Zagreb; Croatia); the International Martial Arts and Combat Sports Scientific Society (IMACSSS) by Professor Wojciech Cynarski (University of Rzeszów; Poland); the International Association for Taekwondo Research (IATR) by John A. Johnson (Keimyung University; Korea); the Society for the Study of Philosophy and the Martial Arts by Professor Joseph Lynch (Philosophy at California Polytechnic State University; USA); the American Philosophical Society by Professors Ronald Dziwenka (Salisbury University; USA), Joseph Lynch (Philosophy at California Polytechnic State University; USA), and Allan Bäck (Kutztown University; USA); the Phoenix Group by Master Suzan Crochet (ITF Independent National Organization \#78); and the American Amateur Athletic Union (AAU) by Master Justin Castillo (USA).

The conference was held over two days. The first day was separated into three sessions: Pedagogy, Philosophical Theories, and Competition Philosophy. Following in the iACT tradition, which in this regard is different to that of many similar scientific meetings, there were no keynote speakers. Each session had either five or six presenters. Presenters were allotted fifteen minutes to present their research. Each session was followed by a 30-minute Q\&A session in which all 
presenters formed a panel and fielded questions from the audience. The organizers also scheduled a 60-minute open forum for presenters and audience members to mingle at the end of the first day.

All presenters possessed advanced or terminal degrees in their research fields but were chosen by the organizing committee due to their status as international academic presenters, ranking as taekwondo masters, and/or previous success at the Olympic Games or World Taekwondo Championships as athletes and coaches. Each speaker had presented at other international academic conferences.

The second day of iACT 2019 was dedicated to the Saving Kyrougi Workshop, a three-hour guided participatory clinic organized and directed by Tim Ghormley, Stanford University's Taekwondo Coach and Director of Facilities and Special Projects for Stanford Athletics. Attendees were invited to list the problems facing Olympic taekwondo sparring and participate in a hands-on, problem-solving seminar to "[p]ropose viable solutions," "(e)xamine the potential drawbacks of any and all remedies," and "(c)reate a roadmap to improvement and a platform for reform" (iACT, 2019, p. 14) to resolve those issues.

Although other academic taekwondo conferences have been organized around the world, iACT 2019 is the most significant to date: organizing iACT 2019 at Stanford University valorized the academic discipline of Academic Taekwondo and the academics' research. This report intends to present the most poignant of those voices as well as detail the conference's events and major presentations.

\section{Notes on Terminology}

In accordance with similar publications on taekwondo academics, the spelling of taekwondo was used to avoid confusion. Taekwon-Do is used by the ITF to separate the physical aspects of the art (tae meaning "foot" and kwon meaning "hand" or "fist") from its philosophical components (Do meaning "the way" or "path" of life). WT prefers the plainer Romanized spelling as used herein. For the sake of simplicity, the latter was chosen for this article.

\section{The Conference}

Similar to the first iACT event (iACT, 2015), iACT 2019 held a two-day academic conference that predominately featured social science research. The first iACT conference in 2015 featured a second day of practical (i.e., physical) martial arts practice with both ITF and WT world champions and Olympic gold medalists, respectfully (iACT 2015), similar in vein to the recent International Martial Arts and Combat Sports Scientific Society (IMACSSS) conference in Poland (Johnson, 2018). iACT 2019 returned to a two-day format, albeit with a guided workshop rather than a practical seminar on the second day.

The opening speeches from Dr. Dziwenka, Dr. Johnson, Dr. Zur, and Coach Ghormley set the tone for the first day's events. Dr. Dziwenka, the iACT President, was professional and set an academic tone for the conference. Dr. Johnson, the iACT Vice President, detailed the conference's history and dedication to including ITF research in a field heavily influenced by WT researchers. Dr. Zur established a more personal tone for the conference by highlighting her long and successful relationship with taekwondo and academics. Likewise, Coach Ghormley discussed his career in taekwondo coaching and the significance of the conference. Thus, an overall atmosphere of friendly academic discourse was established at the outset.

The first session was dedicated to pedagogical research. Noted European professor and Council Member of World Taekwondo Europe Fronjo Prot (Zagreb University; Zagreb, Croatia) spoke first on his research on the "50 Years of Taekwondo Teaching Evolution as an Educational and Cultural Example: A Case Study from Croatia." He highlighted the history of taekwondo in his country beginning with the first taekwondo demonstration in Croatia on May 28, 1968, an event commemorated by the Croatian government with a plaque. Professor Prot emphasized the importance that taekwondo can have on a person's life and a sport culture from an autoethnographic approach, which underscored the often introspective and personal tone for the conference. 
Drs. John A. Johnson (Keimyung University; Daegu, ROK) and Tobias Winright (Saint Louis University; St. Louis, MO USA) followed with presentations on taekwondo as soft power. Professor Johnson explored the history of taekwondo diplomacy and explained how it began being used for peaceful means almost since its inception. He linked the history of taekwondo diplomacy to its pedagogy and the mission statements of both WT and ITF taekwondo organizing bodies. Likewise, Professor Winright discussed the paradox of taekwondo, "an inherently violent" (Johnson, 2018 May, p. 58) activity, as a means for peace through a Christian lens. Together, Professors Johnson and Winright continued Lewis's discussion on the paradox of using a martial art/combat sport for peace (Lewis, 2016; 2017).

The final presenter of the session, ITF Master Suzan Crochet, discussed the role of fear in taekwondo and provided practical solutions on how instructors can teach elite-level athletes and average students to overcome it. Two other presenters were scheduled for the session, but they were unable to attend for personal reasons. In lieu of Dr. George Vitale, his long-time mentor and fellow grassroots taekwondo diplomacy activist Grand Master Woo Jin Jung (Tae Kwon Do Times) gave an abbreviated presentation on his personal work to bridge ties between the ROK, the Democratic People's Republic of Korea (DPRK), and the United States, which helped emphasize the importance of taekwondo diplomacy as shared previously in the day.

The second session focused on taekwondo philosophy. Four presenters gave informative and diverse presentations; a fifth presenter (Hyeong Seok Song; Keimyung University; Daegu, ROK) was scheduled but was unable to attend. Dr. Young Sun Kim (Yonsei University; Kukkiwon; ROK) spoke on the Kukkiwon's newly-updated taekwondo philosophy. He outlined and defined the Kukkiwon's new official concept of taekwondo spirit that will be published in all forthcoming Kukkiwon textbooks. This contemporary understanding of taekwondo, according to Dr. Kim, was necessary in order to distinguish Olympic taekwondo from General Choi Hong Hi's ITF-style taekwondo. His theme of "Overcoming oneself and then benefiting the world" summarized his team's findings as well as provided the theme for iACT 2019. Interesting, the research project independently verified the pedagogical aspects of Professor Johnson's presentation and previous research (Johnson, 2017).

Drs. Ron Dziwenka, Joseph Lynch (California Polytechnic State University; San Luis Obispo, CA USA), and Allan Bäck (Kutztown University; Kutztown, PA USA) (Figure 2) spoke next on various topics of following on their previous presentations. Professor Dziwenka's explicated how fundamental constituent elements within the paradigms of martial arts practice, physical education, bodily awareness, East Asian philosophy, and meditation may align with each other, which was a continuation of his work on the Buddhist concept of sudden awakening, gradual cultivation (SA/GC) toward a grand unified theory of practice (Dziwenka 2014; iACT 2015). Professor Lynch also continued his ongoing research to correlate Plato's discussion of how the outcomes of martial arts practice provide psychological benefits to the practitioner (Lynch, 2010). Professor Bäck, who was identified as a progenitor of Academic Taekwondo, spoke bluntly about the lack of a true philosophy of taekwondo by asserting that the moral concepts (e.g., the taekwondo tenets) are stated too elusively to be the bedrock of a philosophy. Although he did not reference Lewis' recent blog article on this very same subject (Lewis, 2018 July), when examined together the two authors create a strong argument for the lack of a legitimate taekwondo philosophy in the true academic sense

The final session consisted of expert opinions on the state of Olympic taekwondo. Following from Professor Bäck's presentation, Professor Udo Moenig (Youngsan University; Youngsan, ROK) spoke on the history and what he considers to be a fabricated taekwondo philosophy. Due to what he feels are nationalistic intentions, taekwondo philosophy "appear(s) fanciful and hollow" (iACT, 2019, p. 50) and does not follow logically with more modern sport practices. Further explicating the negativity surrounding of modern taekwondo sport, Professor Steven Capener (Seoul Women's University; ROK) provided an account of how sport taekwondo has deteriorated ethically. He related how the match fixing scandal after the 2000 Olympic Games lead to rule changes. He then stated how the use of electronic scoring equipment aggravated the problems Olympic taekwondo faces since competitors now must merely touch or scrape the electronic sensors in their protective gear to gain points. Grand Master Herb Perez, a gold medalist in taekwondo at the 1992 Barcelona 
Olympics, in a presentation similar to one he made in Seoul, ROK in 2017 at the Korean National Sport University, stated comparable sentiments very passionately (Perez, 2017).

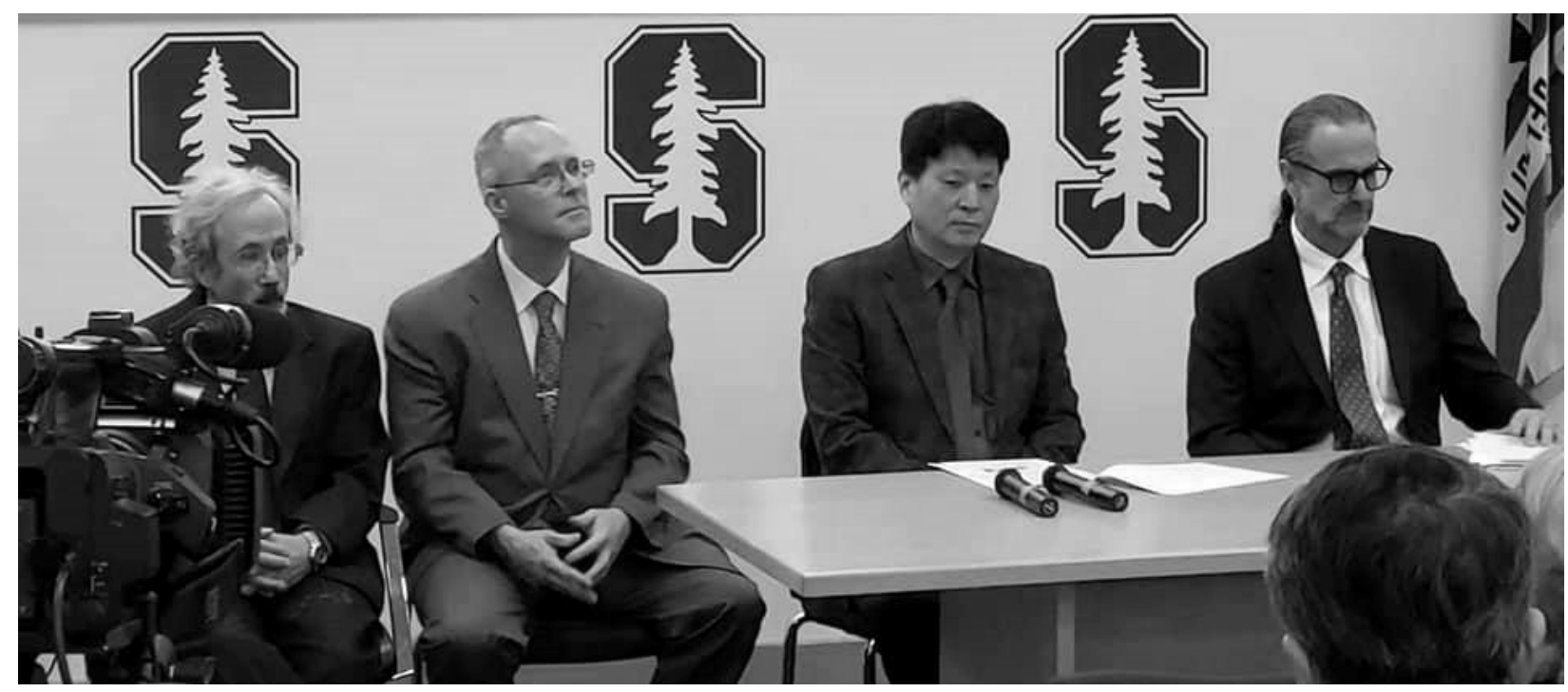

Figure 2. The iACT 2019 Philosophical Theories Session. From left to right, Drs. Allan Bäck, Ron Dziwenka, Young Sun Kim, Joseph Lynch participate in the session's Q\&A panel discussion.

Coach Ghormley took the reins of iACT 2019 on its second day by leading the Saving Kyorugi Workshop. During the three-hour-plus, interactive discussion, he invited the participantsmany of whom were former elite taekwondo athletes, taekwondo masters and students, and/or current coaches-to posit their grievances of Olympic taekwondo. Ideas mentioned included the problems incurred by electronic scoring equipment and the lack of involvement of coaches and athletes in WT's decision-making processes. Participants were then asked to gather into groups and discuss their opinions and possible solutions. Each group proffered their views when Coach Ghormley led a large group discussion.

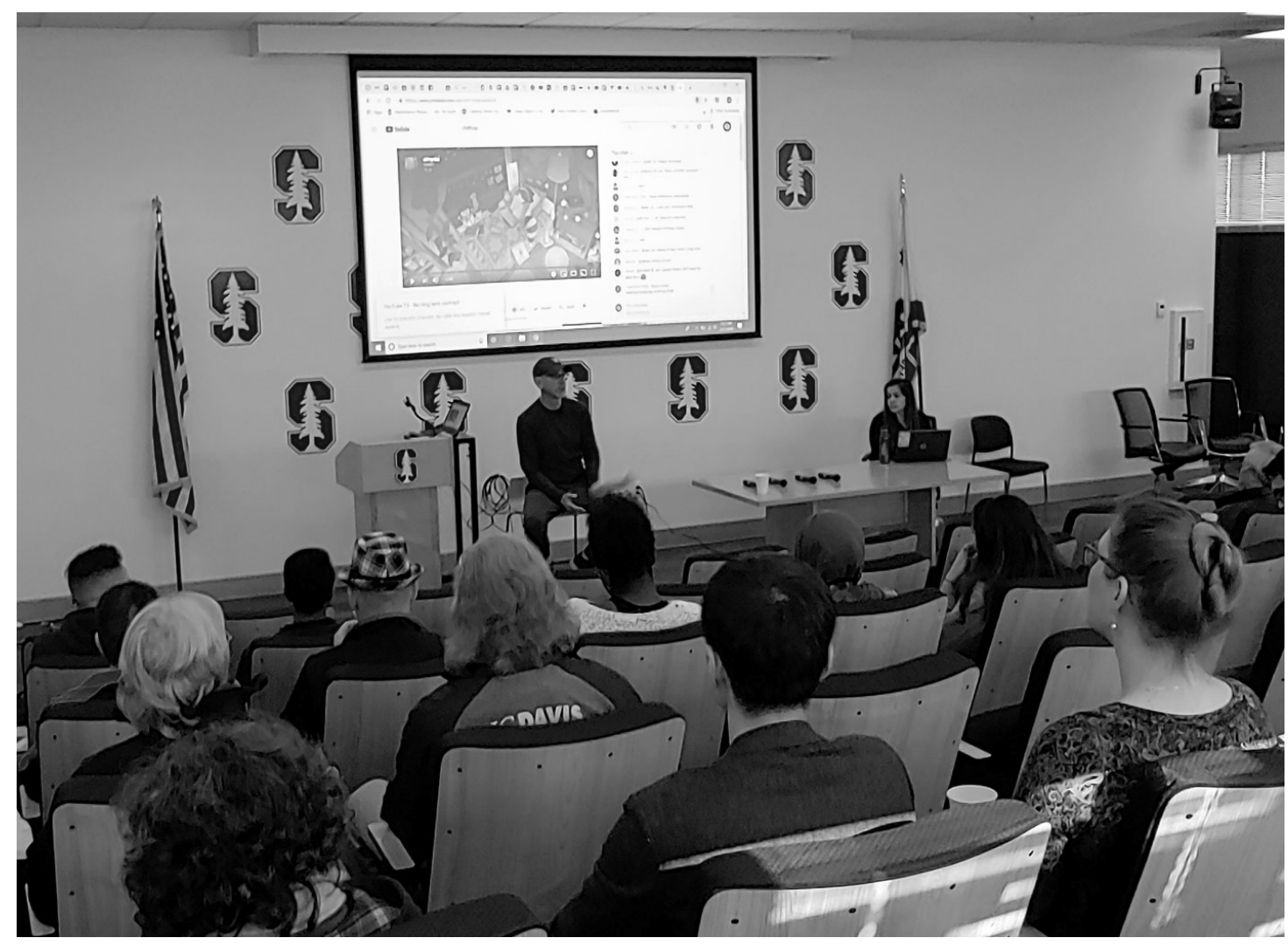

Figure 2. The iACT 2019 Saving Kyorugi Workshop. Stanford University's Taekwondo Coach and Director of Facilities and Special Projects for Stanford Athletics. Tim Ghormley seated facing the audience. 
The entire conference was videoed, recorded, and streamed live across iACT's Facebook site, allowing information to be delivered worldwide instantly. There were technical problems during the first session (e.g., feedback from the microphones), but in general the technological tools offered by Stanford University allowed iACT 2019 to reach an international audience. Of significant importance were the thousand plus hits from across the globe on iACT's Facebook site during Saturday's conference. While this might seem a modest impact, taking in consideration the specificity of the event and the global community of taekwondo academics, this number of interested viewers indicates a strong interest in Academic Taekwondo.

\section{Conclusions and recommendations}

iACT 2019 offered several new alternatives to how academic conferences may be organized. Firstly, the employment of video and internet technologies allowed the live-streamed content to reach a global audience. This served to not only spread the information live to anyone with an internet connection but also enabled the ideas and conclusions made at the conference to reach individuals who need it but were unable to attend. Coupled with the archived recordings that will be available on iACT's Facebook site and website, here, then, is the answer to the question that all academic conferences organizers have longed asked: "How do we get the information to the people who need it?"

While the real-time streaming on Facebook and the subsequent availability of viewing the conference's video allowed for a wider audience, the conference's findings-especially those produced during the workshop-published in a peer-review article would allow a more critical dissemination of the topics presented. Additionally, future conferences should give plenty of notice so a viral "word of mouth" can be garnered. Allowing online participants to participate in the Q\&A session somehow would also maximize the inclusiveness of the conference.

One interesting observation about Academic Taekwondo as a research field is that there are many learned individuals with valuable contributions that could shape the field for years to come. This was evidenced by the great number of excellent presentations at this year's conference; however, few of these individuals are publishing with frequency. As mentioned in iACT Vice President John A. Johnson's opening remarks, ITF taekwondo researchers in particular are not very active in publishing. One of iACT's goals is to stimulate all areas of taekwondo research, but this encouragement stops when the conference ends. To further this goal, iACT organizers should require all presenters to provide proof that they have submitted their papers for publication in academic journals.

iACT 2019, like the two previous conferences, featured a wide range of social science research. While the scholars and researchers were chosen due to their social research fields, iACT could widen its focus to include the vast amount of natural science research on taekwondo. Other taekwondo-focused conferences take a more multidisciplinary approach by including all research fields (Kubala, Cynarski, Swider, 2019). Since iACT wishes to be inclusive of all taekwondo research fields, it may be time for it open its doors to the natural sciences as well. Doing this would widen, and possibly deepen, interest in Academic Taekwondo while providing more taekwondo scholarresearchers with an outlet to present their findings to a global audience.

Finally, iACT 2019 did something that no previous academic or sport-focused taekwondo organization managed to do. By holding the conference at Stanford University and in partnership with Stanford's Center for East Asian Studies and Stanford Athletics, this conference legitimized Academic Taekwondo. Previously, studies of taekwondo had been always tied to other disciplines (e.g., Biomechanics, Sports Psychology, Pedagogy, etc.). Stanford University is renowned as the only such institution in the world to champion academic and athletic pursuits equally. It is therefore no understatement that holding iACT 2019 with Stanford University's Department of East Asian Studies and Stanford Athletics gave weight to taekwondo's researchers and their ideas and, possibly for the first time, validated taekwondo as an academic research field.

\section{Funding}

This research was supported by the Keimyung University research grant of 20180269. 


\section{References}

Dziwenka, R. (2014). Applying a Buddhist paradigm of spiritual practice to contemporary martial art/martial sport study. Journal of the International Association of Taekwondo Research, 1(1), 14-21.

International Academic Conference for Taekwondo (iACT). (2015). Proceedings from WTF-iACT 2015: Taekwondo as a Martial Art \& Martial Sport in 2015: A Collaboration of Physical Training \& Academic Discourse for All. New Mexico State University, Los Cruses, NM USA.

International Academic Conference for Taekwondo (iACT). (2019). Proceedings from iACT 2019: Overcoming the Self to Benefit the World. Stanford University; Stanford, CA USA.

Johnson, J. A. (2017). From technique to way: an investigation into Taekwondo's pedagogical process. Ido Movement for Culture. Journal of Martial Arts Anthropology, 17(4), 3-13. doi: 10.14589/ido.17.4.2

Johnson, J. A. (2018, May). Resolving Taekwondo's inherent violence problem. TaeKwonDo Times, $38(3), 58-59$.

Johnson, J. A., Lewis, S. (2018). Report on the Conference for the 100th Anniversary of Choi Hong Hi: Taekwon-Do and Life; How to View Choi Hong Hi. Revista de Artes Marciales Asiáticas, (13)2: 177-183. doi: 10.18002/rama.v13i2.5628

Kubala, K., Cynarski, W. J., Świder, P. (2019). Three trips in one plane: martial arts and combat sports conferences in Muju, Osaka, and St. Petersburg. Physical Activity Review, 7, 114-124. doi: $10.16926 /$ par.2019.07.14

Lewis, S. (2017). Problems with using Taekwondo as a sport for peace promotion. International Association for Taekwondo Research. Proceedings from The $6^{\text {th }}$ International Symposium for Taekwondo Studies. Muju, Korea.

Lewis, S. (2018, July 19). There is no such thing as Taekwon-Do philosophy-or is there? Sim Soo Kwan. Retrieved from http://sooshimkwan.blogspot.com

Lewis, S. R. C. (2016). Promoting Peace, Practising War: Mohism's Resolution of the Paradoxical Ethics of War and Self-Defence in East Asian Martial Arts (Unpublished doctoral dissertation); Kyung Hee University, Yongin, Korea.

Lynch, J. J. (2010). Plato and the Shaolin monks square off. In G. Priest \& D. Young (Eds.), Martial Arts and Philosophy: Beating and Nothingness (pp. 35-45). Chicago and La Salle, IL: Open Court.

Perez, H. (2017, September 1). Developmental direction and issues of electronic protective gears in Taekwondo. Proceedings from 2017 World Taekwondo Forum. Taekwondo Promotion Foundation. Seoul, Korea.

\section{Author's biographical data}

John A. Johnson (USA) is an assistant professor in the Department of Taekwondo at Keimyung University (Daegu, South Korea). He received his PhD from the Department of Taekwondo at Kyung Hee University (Suwon, South Korea) and was the first ITF Taekwon-Do practitioner to do so. Dr. Johnson's research focuses on Taekwondo international relations, pedagogy, and philosophy, but he has published in other academic fields as well. He is the executive director of the International Association for Taekwondo Research (www.actataekwondo.com) and vice president of the International Academic Conference for Taekwondo (www.iactkd.com). Email: beowulf600@gmail.com 